\title{
Assessing the utility of Hsp90 gene for inferring evolutionary relationships within the ciliate subclass Hypotricha (Protista, Ciliophora)
}

Qi Zhang ${ }^{1,2+}$, Jiahui $\mathrm{Xu}^{1,2+}$, Alan Warren ${ }^{3}$, Ran Yang ${ }^{1}$, Zhuo Shen ${ }^{4,5^{*}}$ and Zhenzhen $\mathrm{Yi}^{1,2^{*}}$

\begin{abstract}
Background: Although phylogenomic analyses are increasingly used to reveal evolutionary relationships among ciliates, relatively few nuclear protein-coding gene markers have been tested for their suitability as candidates for inferring phylogenies within this group. In this study, we investigate the utility of the heat-shock protein 90 gene (Hsp90) as a marker for inferring phylogenetic relationships among hypotrich ciliates.

Results: A total of 87 novel Hsp90 gene sequences of 10 hypotrich species were generated. Of these, 85 were distinct sequences. Phylogenetic analyses based on these data showed that: (1) the Hsp90 gene amino acid trees are comparable to the small subunit rDNA tree for recovering phylogenetic relationships at the rank of class, but lack sufficient phylogenetic signal for inferring evolutionary relationships at the genus level; (2) Hsp90 gene paralogs are recent and therefore unlikely to pose a significant problem for recovering hypotrich clades; (3) definitions of some hypotrich orders and families need to be revised as their monophylies are not supported by various gene markers; (4) The order Sporadotrichida is paraphyletic, but the monophyly of the "core" Urostylida is supported; (5) both the subfamily Oxytrichinae and the genus Urosoma seem to be non-monophyletic, but monophyly of Urosoma is not rejected by AU tests.

Conclusions: Our results for the first time demonstrate that the Hsp90 gene is comparable to SSU rDNA for recovering phylogenetic relationships at the rank of class, and its paralogs are unlikely to pose a significant problem for recovering hypotrich clades. This study shows the value of careful gene marker selection for phylogenomic analyses of ciliates.
\end{abstract}

Keywords: Ciliates, Heat-shock protein 90 gene, Hypotricha, Phylogeny

\footnotetext{
* Correspondence: shenzhuo@mail.sysu.edu.cn; zyi@scnu.edu.cn

${ }^{\dagger}$ Qi Zhang and Jiahui Xu contributed equally to this work.

${ }^{4}$ Institute of Microbial Ecology and Matter Cycle, School of Marine Sciences,

Sun Yat-sen University, Zhuhai 519000, China

'Guangzhou Key Laboratory of Subtropical Biodiversity and Biomonitoring,

School of Life Science, South China Normal University, Guangzhou 510631,

China

Full list of author information is available at the end of the article
}

(c) The Author(s). 2020 Open Access This article is licensed under a Creative Commons Attribution 4.0 International License, which permits use, sharing, adaptation, distribution and reproduction in any medium or format, as long as you give appropriate credit to the original author(s) and the source, provide a link to the Creative Commons licence, and indicate if changes were made. The images or other third party material in this article are included in the article's Creative Commons licence, unless indicated otherwise in a credit line to the material. If material is not included in the article's Creative Commons licence and your intended use is not permitted by statutory regulation or exceeds the permitted use, you will need to obtain permission directly from the copyright holder. To view a copy of this licence, visit http://creativecommons.org/licenses/by/4.0/ The Creative Commons Public Domain Dedication waiver (http://creativecommons.org/publicdomain/zero/1.0/) applies to the data made available in this article, unless otherwise stated in a credit line to the data. 


\section{Background}

Evolutionary relationships of many ciliated protists (ciliates) remain unknown due to difficulties in species identification caused by their small size, complex morphological characters and high species diversity, although this topic is vital for understanding the evolution of life on Earth [1-4]. Most published molecular phylogenetic trees of ciliates are based on rDNA sequences, including the small subunit rDNA (SSU rDNA), large subunit rDNA (LSU rDNA) and the internal transcribed spacer (ITS) region [5-8]. All presently used markers give rise to artifacts in phylogenetic reconstructions resulting in the recovery of ambiguous relationships in gene trees $[9,10]$. Analysis of sequences of multiple unlinked loci having different evolutionary histories, as opposed to linked SSU rDNA, LSU rDNA, and ITS regions, is necessary since phylogenetic bias might be common to loci that are linked [11]. Hence, protein-coding genes, such as alpha-tubulin, actin, Hsp70 and histone $\mathrm{H} 4$ genes, are increasingly used to reconstruct ciliate phylogenies $[1,3,12-17]$. With the development of phylogenomics, it is now possible to reconstruct phylogenetic relationships among ciliates based on analyses of hundreds of proteincoding genes [1, 18-22]. However, only a few of these protein-coding gene markers in comparatively few taxa have been tested for their suitability as candidates for inferring phylogenetic relationships among ciliates [23-25].

It has previously been shown that heat shock protein 90 (Hsp90) can resolve evolutionary relationships among eukaryotic taxa at high taxonomic rank, including alveolates and deep-branching dinoflagellates [26-29], and possibly also at genus level, e.g., Paramecium and Tetrahymena [30]. Furthermore, Hsp90 is ubiquitous and highly conserved in eukaryotic cells making it easy to amplify using PCR [31, 32]. As in other protein-coding genes used for molecular phylogenies, paralogs caused by gene duplication, especially recent ones, might be the biggest disadvantage of using $\mathrm{Hsp} 90$ in phylogenetic analyses [3, 33, 34]. Notably, gene duplications in ciliates are common due to extremely high copy numbers of genes caused by unique features such as nuclear dimorphism $[6,35,36]$. Hence, it is necessary to test whether Hsp90 gene paralogs will confound phylogenetic analyses before this gene is widely used for determining evolutionary relationships among ciliates.

The subclass Hypotricha is mainly defined by the patterns of ventral cirri arranged either in longitudinal files or in scattered groups and represents one of the most diverse groups within the Ciliophora [37]. This subclass has been the subject of many taxonomic revisions, particularly in the past three decades [1,38-43]. Phylogenetic relationships within the Hypotricha are still poorly understood and the rapidly growing molecular phylogenetic studies have consistently questioned monophylies and assignments of many taxa [44-46].
In the present study, phylogenetic analyses based on the Hsp90 gene were carried out for 10 species (11 populations) of hypotrichs. The main aims were to examine whether Hsp90 is a suitable gene marker for resolving evolutionary relationships among ciliates using Hypotricha as an example, and to re-evaluate phylogenetic relationships within the subclass Hypotricha based on new Hsp90 sequence data.

\section{Results}

\section{Hsp90 gene sequences of hypotrich ciliates}

We obtained a total of 87 novel Hsp90 gene sequences from 11 populations of hypotrichs (Table 1 ). In order to avoid data redundancy we only used 85 distinct sequences in downstream analyses. The amplified fragment length of the Hsp90 gene was 1089-1119 base pairs (bp) with 41.2$60.1 \%$ GC content of which 543 sites $(47.4 \%)$ were variable. Numbers of variable sites were highly divergent within each population, ranging from 16 (1.4\%, Pseudokeronopsis rubra) to 216 (18.9\%, Ponturostyla enigmatica). The third codon position exhibited the highest level of variation (42.0\%). A total of 74 distinct amino acid sequences were detected among the 85 distinct nucleotide sequences. The 11 identical amino acid sequences were removed. The numbers of parsimony-informative and variable sites varied greatly at intra-population level. For instance, only one parsimony-informative site and five variable sites were present in Pseudokeronopsis rubra, while 48 and 67, respectively, were observed in Ponturostyla enigmatica (Fig. 1a).

Average nucleotide and amino acid pairwise distances within 11 hypotrich populations ranged from 0.0066 (Pseudokeronopsis rubra) to 0.1461 (Ponturostyla sp.), and 0.0051 (Pseudokeronopsis rubra) to 0.0843 (Ponturostyla enigmatica), respectively (Fig. 1b). Average interspecific pairwise distances varied from 0.1062 (Pseudokeronopsis erythrina vs. P. rubra) to 0.3156 (Hypotrichidium paraconicum vs. Neowallackia sp.) for nucleotides, and 0.0424 (Pseudokeronopsis erythrina vs. P. rubra) to 0.1966 (Pseudokeronopsis erythrina vs. Pseudoamphisiella quadrinucleata) for amino acids (Table S1).

\section{Phylogenetic trees}

In the Hsp90 amino acid (HSP90-Amino) tree, Oligohymenophorea and Spirotrichea were the only monophyletic classes with more than one representative species included in the analyses (Fig. 2). Another two classes, i.e. Heterotrichea and Phyllopharyngea, contain only one sequence each. Within Hypotricha, the orders Sporadotrichida and Urostylida were both monophyletic and order Stichotrichida was represented by only one species. Two out of six hypotrich families (Oxytrichidae and Urostylidae) represented by more than one species were polyphyletic. At the genus level, there was no sister relationship 


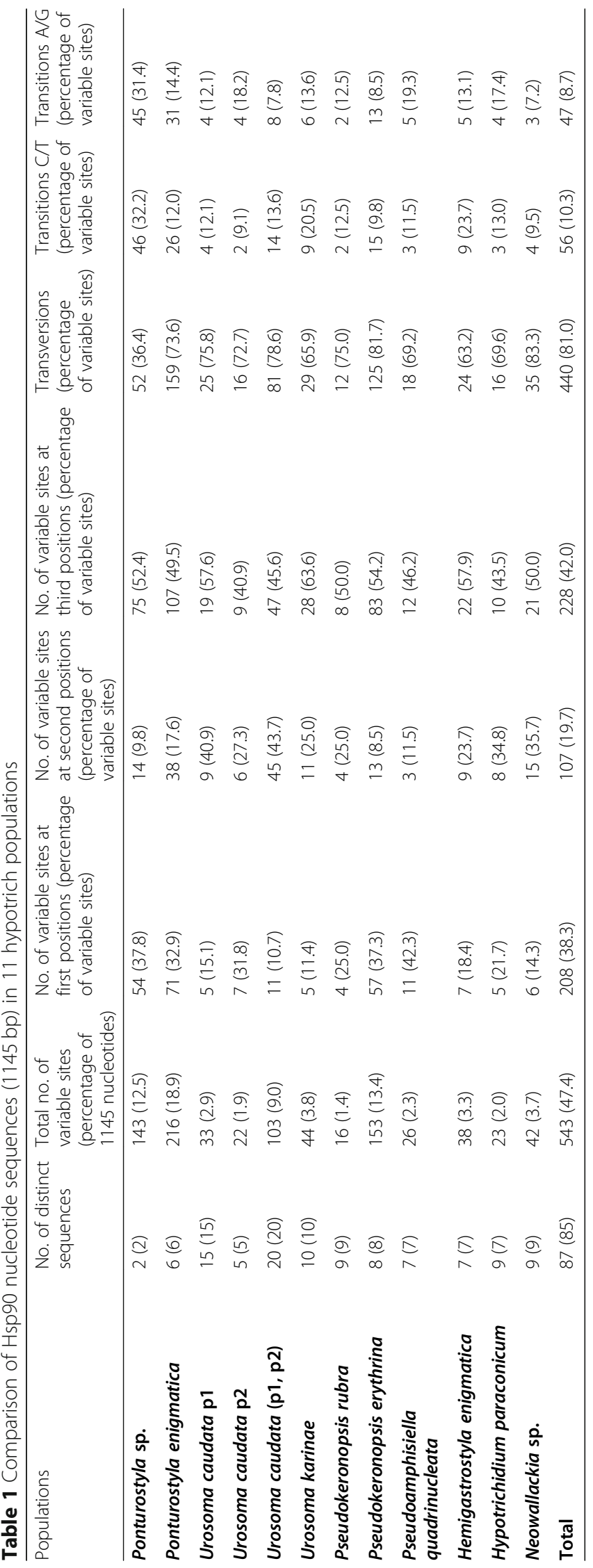




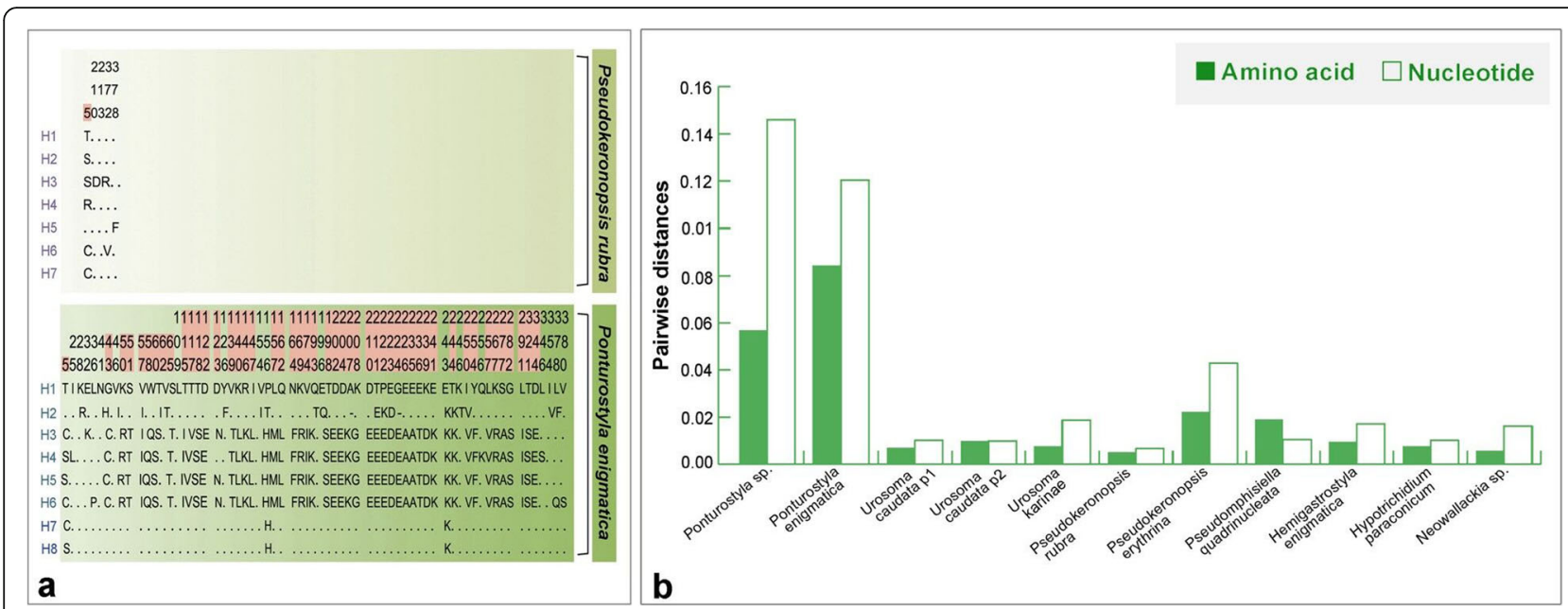

Fig. 1 Amino acid variable sites and parsimony-informative sites in Pseudokeronopsis rubra and Ponturostyla enigmatica (a), and intra-population genetic distances of Hsp90 gene amino acid and nucleotide sequences (b). a Only variable sites are shown: parsimony-informative sites are shaded red; $\mathbf{b}$ genetic distances of amino acid and nucleotide are green solid and hollow boxes respectively

between the two representatives of Urosoma, i.e., $U$. caudata and $U$. karinae, and sequences of two Ponturostyla species fell into three different clades. In contrast, the two Pseudokeronopsis species clustered together in a strongly supported clade ( $98 \% \mathrm{ML}, 1.00 \mathrm{BI})$. Only $U$. caudata was represented by more than one population (U. caudata $\mathrm{p} 1$ \& p2), and their sequences formed a clade with reliable support (97\% ML, $1.00 \mathrm{BI}$ ). For each of six populations, i.e., Urosoma karinae (99\% ML, 1.00 BI), Neowallackia sp. (100\% ML, $1.00 \mathrm{BI})$, Pseudoamphisiella quadrinucleata (99\% ML, 1.00 BI), Hypotrichidium paraconicum (99\% ML, 1.00 BI), Hemigastrostyla enigmatica (100\% ML, 1.00 BI) and Pseudokeronopsis rubra (93\% ML, $1.00 \mathrm{BI})$, all sequences formed high to maximally supported clades. For five other populations, i.e., $U$. caudata $\mathrm{p} 1, U$. caudata $\mathrm{p} 2$, Ponturostyla enigmatica, Ponturostyla sp. and Pseudokeronopsis erythrina, this was not the case. For example, one sequence of Pseudokeronopsis erythrina grouped within the $P$. rubra clade. Within the class Oligohymenophorea, two sequences of Paramecium tetraurelia branched off with full support (100\% ML, $1.00 \mathrm{BI})$ and clustered with Tetrahymena bergeri (AY391257) with moderate or low support ( $82 \% \mathrm{ML}, 0.75 \mathrm{BI})$.

The topologies of the Hsp90 nucleotide (HSP90-Nuc) trees (Fig. 3) and Hsp90 nucleotide trees without third codon positions (HSP90-Nuc12) (Fig. 4) corresponded closely with that of the HSP90-Amino tree (Fig. 2), although there were three notable differences. Firstly, sequences of Urosoma caudata $\mathrm{p} 1$ and $U$. caudata $\mathrm{p} 2$ were separated from each other within a large clade and both populations appeared to be monophyletic in both the HSP90-Nuc and HSP90-Nuc12 trees, whereas they clustered together in the HSP90-Amino tree. Secondly, the clade comprising sequences of Chilodonella uncinata (DQ662856) occupied the basal position in the HSP90-Nuc and HSP90-Nuc12 trees, but it grouped with Oligohymenophorea and Heterotrichea in the HSP90-Amino tree. Thirdly, the subclass Hypotricha was polyphyletic in the HSP90-Nuc and HSP90-Nuc12 trees, but monophyletic in the HSP90-Amino tree.

The topology of the SSU-rDNA tree (Fig. 5a) was almost congruent with the HSP90-Amino tree (Fig. 2). The major difference was that the two Urosoma species clustered together in the SSU-rDNA tree, whereas they were separated into different clades in the HSP90-Amino tree.

The topology of the SSU-HSPNuc12 tree (Fig. 5b) was nearly identical to that of the SSU-rDNA tree (Fig. 5a) except that Urostylida/Urostylidae was monophyletic only in the SSU-HSPNuc12 tree (Fig. 5b). The monophyly of the subclass Hypotricha was also recovered in SSU-HSPNuc12 tree which is consistent with the HSP90-Amino and SSU-rDNA trees (Figs. 2 and 5a).

\section{Discussion \\ Is Hsp90 gene a suitable gene marker for inferring hypotrich phylogeny?}

Previous studies have shown that the best way to evaluate the utility of a gene marker is to compare its congruence with other data [9]. Some researchers have suggested that Hsp90 is as good or better than any other single gene marker for inferring eukaryote phylogeny [29]. Here, the reliability of the Hsp90 gene is compared with other gene markers, especially SSU rDNA, based on accepted monophyletic groups at different taxonomic ranks. In the present investigation the class Oligohymenophorea was monophyletic, which is consistent with previous reports based on a variety of gene markers $[3,6,54,55]$. In contrast, the subclass Hypotricha was non-monophyletic in 


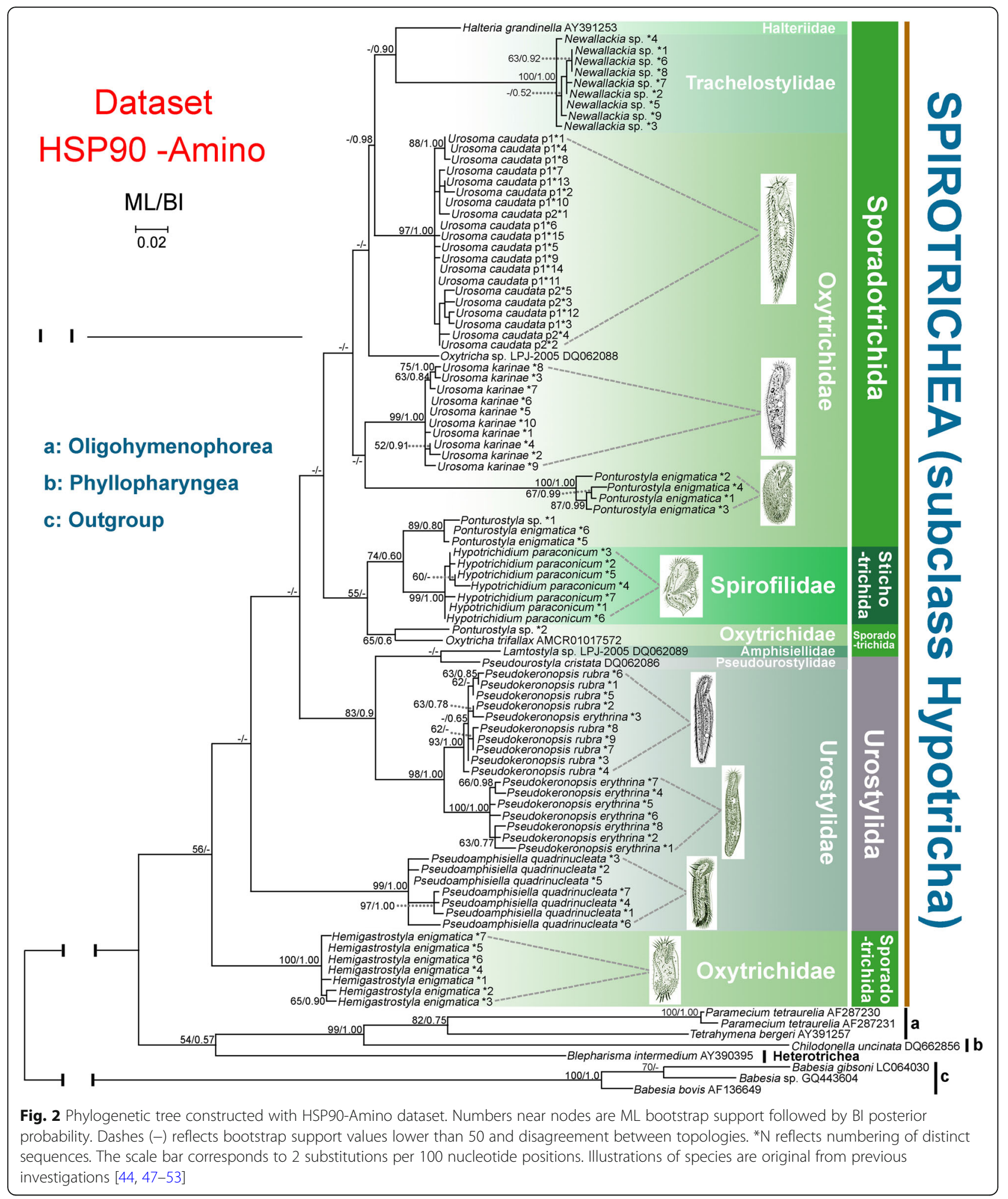

our HSP90-Nuc and HSP90-Nuc12 trees (Figs. 3 and 4) but monophyletic in the HSP90-Amino, SSU-rDNA and SSU-HSPNuc12 trees (Figs. 2 and 5). Non-monophyly in HSP90 trees (Figs. 3 and 4) might be caused by the rapid evolution of Hsp90 gene nucleotide sequences which is not suitable for reconstruction relationships of high-level taxa. It is suggested that amino acid sequences, rather than nucleotide sequences, of the Hsp90 gene are more 


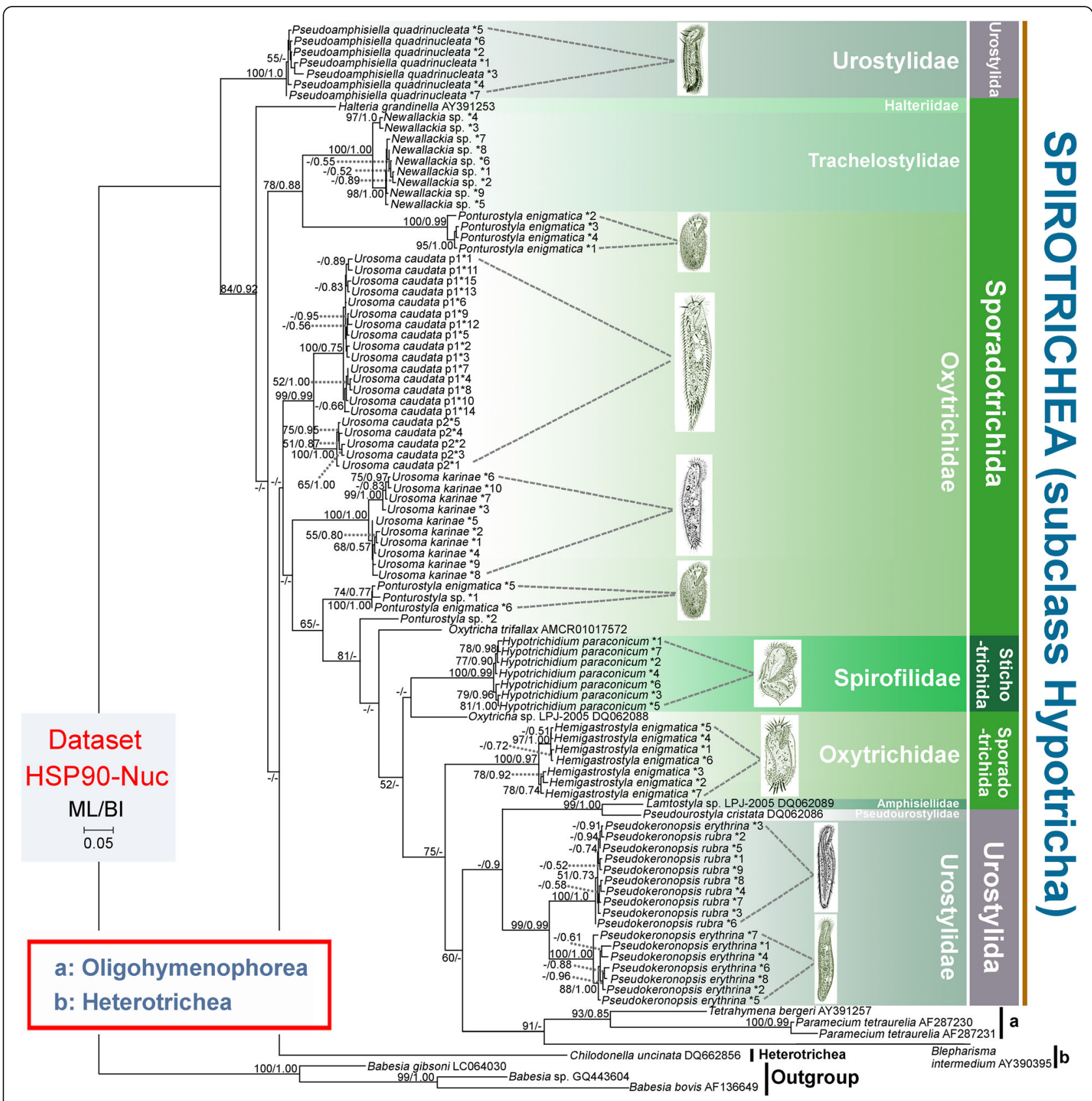

Fig. 3 Phylogenetic tree constructed with HSP90-Nuc dataset. Numbers near nodes are ML bootstrap support followed by BI posterior probability. Dashes (-) reflects bootstrap support values lower than 50 and disagreement between topologies. *N reflects numbering of distinct sequences. The scale bar corresponds to 5 substitutions per 100 nucleotide positions. Illustrations of species are original from previous investigations [44, 47-53]

suitable for the classification of ciliates. The subclass Hypotricha was monophyletic in most previous molecular phylogenetic trees based on a variety of gene markers $[6,56-59]$, although in a few studies it was nonmonophyletic $[1,6,33]$. The utility of the Hsp90 gene is comparable to that of SSU rDNA at class level. Out of three hypotrich genera for which Hsp90 gene sequences from more than one species were available, two (Urosoma and Ponturostyla) were paraphyletic
(Figs. 2 and 3). This suggests that the Hsp90 gene might lack sufficient phylogenetic signal for inferring evolutionary relationships at the genus level. Due to the lack of taxon coverage, we were unable to determine whether the Hsp90 gene yields sufficient phylogenetic signal to determine relationships at order or family levels. The order Sporadotrichida, and two families for which sequences from multiple species were available, were polyphyletic (Figs. 2, 3, 4, 5). 


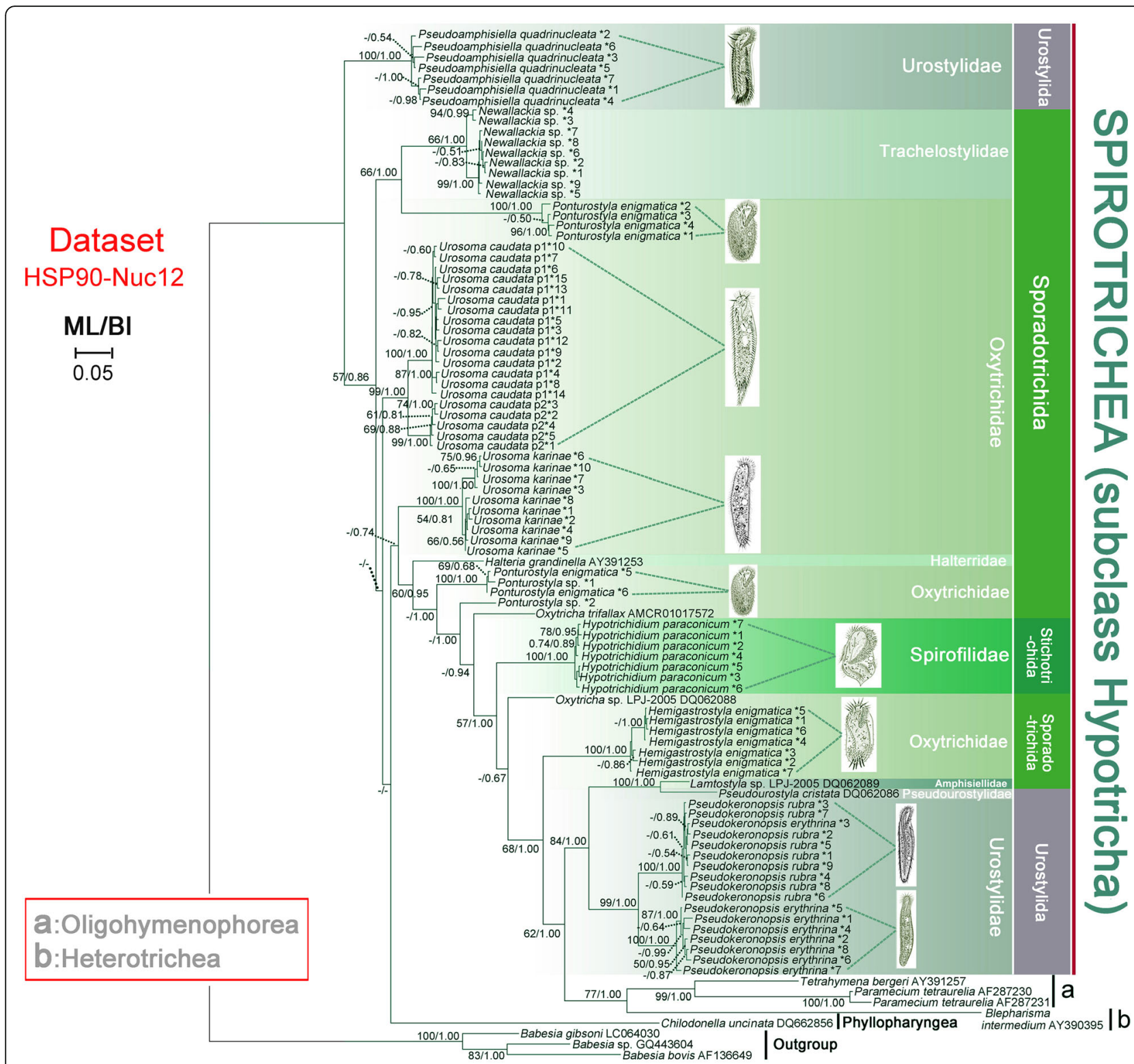

Fig. 4 Phylogenetic tree constructed with HSP90-Nuc12 dataset. Numbers near nodes are ML bootstrap support followed by BI posterior probability. Dashes (-) reflects bootstrap support values lower than 50 and disagreement between topologies. *N reflects numbering of distinct sequences. The scale bar corresponds to 5 substitutions per 100 nucleotide positions. Illustrations of species are original from previous investigations [44, 47-53]

This is consistent with previous findings based on SSU rDNA, actin and alpha-tubulin gene markers [43, 44, 46].

Multiple distinct Hsp90 nucleotide sequences were detected in every species, probably as a result of gene duplications. Of the 11 populations represented by more than one sequence, eight formed a well-supported clade in the HSP90-Nuc tree, the exceptions being Pseudokeronopsis erythrina, Ponturostyla sp. and Ponturostyla enigmatica (Fig. 3). This indicates that the Hsp90 gene duplications are recent and might have occurred after the separation of populations, suggesting that Hsp90 gene paralogs are unlikely to pose a substantial problem in defining hypotrich clades. Similarly, only recent duplication events have been detected in ciliates for the alpha-tubulin gene [17], this being the most widely used protein-coding gene for inferring evolutionary relationships in a range of ciliate groups $[1,13,16,17,25]$. Some studies, however, have concluded that the alpha-tubulin gene might not provide sufficient phylogenetic signal to resolve evolutionary relationships within some groups, e.g., Spirostomum, possibly due to the especially pronounced purifying selection $[16,60,61]$. In the case of the actin gene, the presence of ancient gene duplications 


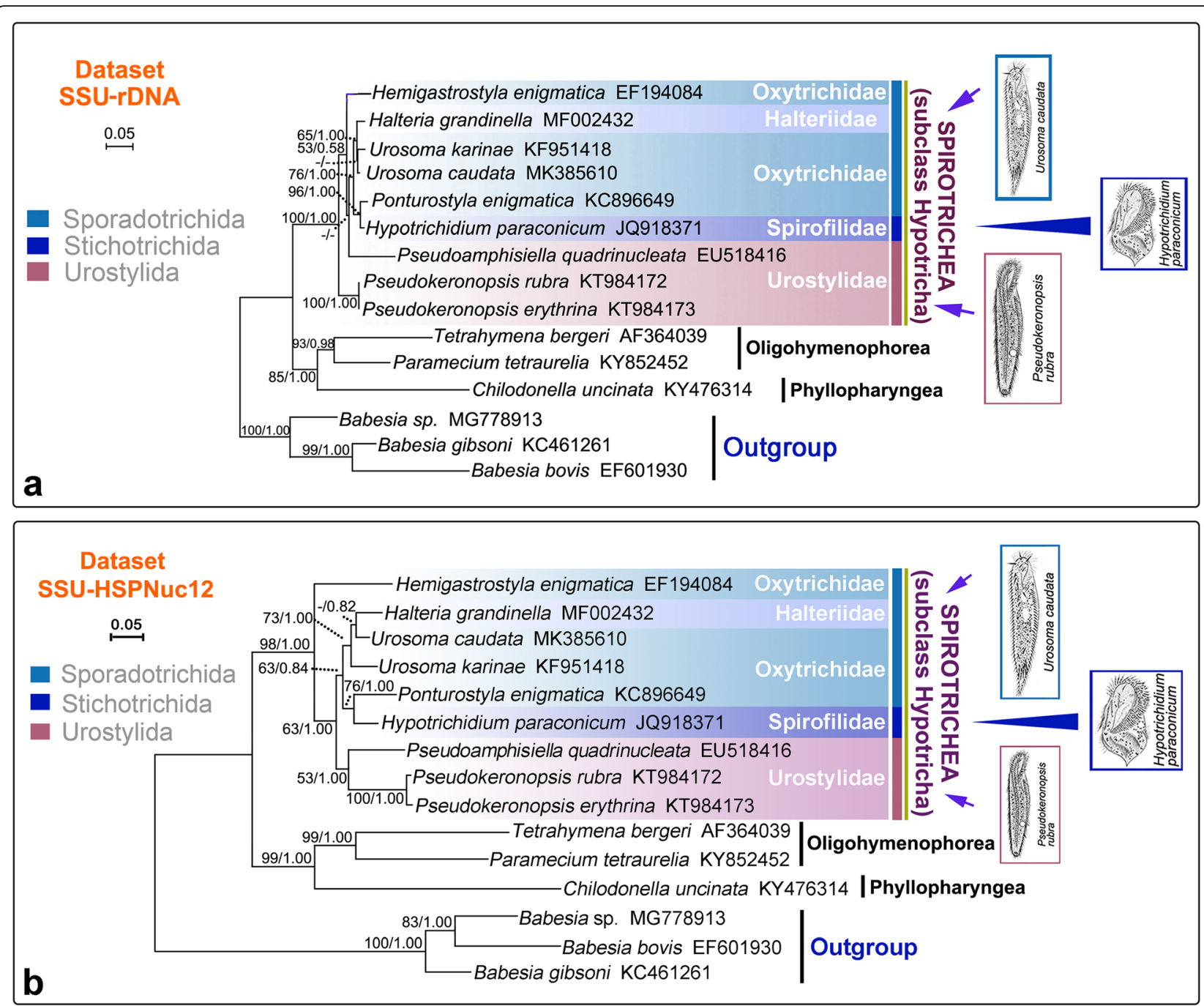

Fig. 5 Phylogenetic trees constructed with SSU-rDNA dataset (a) and SSU-HSPNuc12 dataset (b). Numbers near nodes are ML bootstrap support followed by BI posterior probability. Dashes (-) reflects bootstrap support values lower than 50 and disagreement between topologies. The scale bar corresponds to 5 substitutions per 100 nucleotide positions. Illustrations of species are original from previous investigations [48-50]

and actin isoforms being too divergent means that it is not possible to resolve evolutionary relationships below the rank of class [3]. These findings indicate that gene duplication patterns of different protein-coding genes are variable depending on the gene and the ciliate group. More studies are therefore needed to test more genes and more ciliate groups.

Phylogenetic relationships within the subclass Hypotricha In the present study, each of the orders Sporadotrichida and Stichotrichida were paraphyletic and support values for some clades were low (Figs. 2, 3, 4, 5). This is consistent with previous molecular phylogenetic studies [3, 62-67]. It seems that gene markers with sufficient phylogenetic signal to recover the monophyletic Hypotricha are currently unavailable, although several (e.g., SSU rDNA, LSU rDNA, ITS and alpha-tubulin) have been widely used. This is reasonable considering that classification systems based on morphology, morphogenesis and gene sequences are not concordant with each other, probably due to the high diversity of ciliary and other somatic structures, as well as various modes of cortical development, within the Hypotricha [38-43, 68]. Currently, Hsp90 gene sequence data are available for only one species of Stichotrichida, namely Hypotrichidium paraconicum. Therefore, relationships within this order could not be analyzed. In contrast, several important phylogenetic relationships are recovered within the orders Sporadotrichida and Urostylida.

\section{Sporadotrichida}

It has been suggested that the family Oxytrichidae, which is characterized by typically having 18 frontventral-transverse (FVT) cirri, should be divided into 
two subfamilies, the Oxytrichinae, with a flexible body, and the Stylonychinae, with a rigid body [38, 39]. All genera of Oxytrichidae included in the present study, i.e., Oxytricha, Urosoma, Ponturostyla and Hemigastrostyla belong to the subfamily Oxytrichinae. However, the subfamily Oxytrichinae was not monophyletic in any of the trees (Figs. 2, 3, 4, 5). This is consistent with previous studies based on SSU rDNA [69], actin [3] and alpha-tubulin genes [17], suggesting that the ontogenetic character which characterizes this group, viz. the participation of the posteriormost postoral ventral cirrus in primordia formation, might not be a synapomorphy. Furthermore, approximately Unbiased (AU) tests performed on HSP90-Nuc, HSP90-Nuc12, HSP90-Amino, SSU-rDNA and SSU-HSPNuc12 datasets rejected the monophyly of the subfamily Oxytrichinae $(P<0.05)$ (Table 2). The monophyly of the genus Urosoma was not supported in the HSP90-Nuc, HSP90-Nuc12, HSP90-Amino and SSU-HSPNuc12 trees, although this was not rejected by AU tests $(P>0.05$, Table 2$)$ (Figs. $2,3,4,5 b)$. Furthermore, no support values were revealed for the clade containing two Urosoma species shown in ML analyses based on the SSU-rDNA dataset (Fig. 5a). It is noteworthy that the monophyly of the genus Urosoma was not recovered in previous studies based on SSU rDNA sequences [47, 48]. The genus Urosoma might therefore be an artificial assemblage and its synapomorphies (i.e., frontoventral cirri arrange in a row with anterior cirrus (III/2) located slightly to the left, postoral ventral cirri in a dense cluster behind the buccal vertex, usually with two pretransverse ventral, five transverse cirri, one right and one left row of marginal cirri, and caudal cirri present) might be plesiomorphies of the subclass Hypotricha [38, 48]. Morphological, morphogenetic and molecular data for more taxa are required in order to resolve the systematics of Sporadotrichida.

Table 2 Approximately Unbiased (AU) test results of the monophyly of Oxytrichinae and Urosoma based on different datasets

\begin{tabular}{llll}
\hline Datasets & Topology constraints & $-\mathrm{Ln}^{\mathrm{a}}$ Likelihood & $\mathrm{AU}$ value $(P)$ \\
\hline HSP90-Nuc & Oxytrichinae & $18,926.77844542$ & $<0.001$ \\
& Urosoma & $18,720.53438758$ & $\mathbf{0 . 6 9 3}$ \\
HSP90-Nuc12 & Oxytrichinae & $24,480.25572958$ & $<0.001$ \\
& Urosoma & $24,253.92785203$ & $\mathbf{0 . 5 7 9}$ \\
HSP90-Amino & Oxytrichinae & 6100.82366514 & 0.001 \\
& Urosoma & 6017.78810081 & $\mathbf{0 . 5 7 6}$ \\
SSU-rDNA & Oxytrichinae & 9661.66588815 & 0.001 \\
SSU-HSPNuc12 & Oxytrichinae & $16,370.74872451$ & 0.001 \\
& Urosoma & $16,280.08580004$ & $\mathbf{0 . 7 3 6}$ \\
\hline
\end{tabular}

${ }^{\mathrm{a}}$-Ln $=$ negative value of natural logarithm; $P$ values $>0.05$ in bold

\section{Urostylida}

It is not surprising that Pseudoamphisiella was separated from the "core" Urostylida in most our trees (Figs. 2, 3, $4,5 \mathrm{a})$ since phylogenetic trees based on various gene markers have previously revealed the fragmentation of the order Urostylida into a "core" group and the rest [1, $46,70,71]$. Considering that the monophyly of the "core" urostylid group was consistently recovered and other urostylid taxa usually had no robust assignment in our phylogenetic trees, we suggest that the morphological definition of the order Urostylida needs to be further refined.

\section{Conclusions}

Our investigation indicates that, though lacking sufficient phylogenetic signal at the genus level, the Hsp90 gene is comparable to SSU rDNA for recovering evolutionary relationships at the rank of class and that its paralogs are unlikely to pose a significant problem for recovering hypotrich clades. The Hsp90 gene therefore has significant potential utility for determining the systematics of ciliates. The findings of this study also suggest that careful selection of nuclear protein-coding gene markers is needed for phylogenetic analyses of ciliates.

\section{Methods}

\section{Culturing, DNA extraction, PCR amplification, and sequencing}

All the ciliates used in this study are listed in Table 3. Pure cultures were maintained in Petri dishes at room temperature (approximately $25^{\circ} \mathrm{C}$ ) with rice grains to stimulate the growth of bacteria as food for the ciliates [72]. One or more cells of each culture were repeatedly washed in sterile water with the same salinity as that of the sampling site. Genomic DNA was extracted using REDExtract-NAmp Tissue PCR Kit (Sigma, St. Louis, MO, USA).

PCR amplifications of the Hsp90 genes were performed using a TaKaRa Ex Taq DNA Polymerase Kit (TaKaRa Biomedicals, Japan). The primers used for Hsp90 gene amplification were Hsp90F4 (5' -CGGCAC GTTCTACWSNAAYAARGA-3') and Hsp90R3 (5'GGTCTTTCTTCTGGCGTGTTCAGTGTA-3') [26]. PCR conditions were: $2 \mathrm{~min}$ initial denaturation $\left(95^{\circ} \mathrm{C}\right)$, followed by 35 cycles of $45 \mathrm{~s}$ at $92^{\circ} \mathrm{C}, 45 \mathrm{~s}$ at $48^{\circ} \mathrm{C}$ and $1.5 \mathrm{~min}$ at $72^{\circ} \mathrm{C}$, with a final extension of $10 \mathrm{~min}\left(72^{\circ} \mathrm{C}\right)$. Reactions were run in a total volume of $50 \mathrm{ul}$ containing 5 ul $10 \times$ Ex Taq DNA Polymerase buffer, 5 ul $2.5 \mathrm{mmol} /$ L dNTP mix, 0.4 ul Ex Taq DNA Polymerase, $0.8 \mathrm{ul}$ of each primer $(25 \mathrm{mM}), 2 \mathrm{ul}$ of template DNA, and $36 \mathrm{ul}$ of autoclaved double-distilled water.

After confirmation of the amplified DNA by $1.0 \%$ agarose gel, a single bright band containing the target DNA was purified using the Universal DNA purification 
Table 3 Sampling information of 11 ciliate populations sequenced in this study

\begin{tabular}{|c|c|c|c|c|}
\hline Organisms & Sampling locality Location & $\begin{array}{l}\text { Sampling Salinity } \\
(\% 0)\end{array}$ & $\begin{array}{l}\text { GenBank } \\
\text { No. }\end{array}$ & $\begin{array}{l}\text { Morphological Data } \\
\text { Sources }\end{array}$ \\
\hline Ponturostyla sp. & Futian Mangrove $\left(22^{\circ} 31^{\prime} \mathrm{N} ; 114^{\circ} 04^{\prime} \mathrm{E}\right)$, Guangdong & 20 & $\begin{array}{l}\text { MN892397 } \\
- \text { MN892398 }\end{array}$ & [53] \\
\hline Ponturostyla enigmatica & Futian Mangrove $\left(22^{\circ} 31^{\prime} \mathrm{N} ; 114^{\circ} 04^{\prime} \mathrm{E}\right)$, Guangdong & 5 & $\begin{array}{l}\text { MN892399 } \\
\text {-MN892404 }\end{array}$ & [53] \\
\hline Urosoma caudata p1 & Nansha Island $\left(22^{\circ} 85^{\prime} \mathrm{N} ; 113^{\circ} 51^{\prime} \mathrm{E}\right)$, Guangdong & 25 & $\begin{array}{l}\text { MN892405 } \\
- \text { MN892419 }\end{array}$ & [48] \\
\hline Urosoma caudata p2 & Futian Mangrove $\left(22^{\circ} 31^{\prime} \mathrm{N} ; 114^{\circ} 04^{\prime} \mathrm{E}\right)$, Guangdong & 8 & $\begin{array}{l}\text { MN892420 } \\
- \text { MN892424 }\end{array}$ & [48] \\
\hline Urosoma karinae & Futian Mangrove $\left(22^{\circ} 31^{\prime} \mathrm{N} ; 114^{\circ} 04^{\prime} \mathrm{E}\right)$, Guangdong & 7 & $\begin{array}{l}\text { MN892425 } \\
- \text { MN892434 }\end{array}$ & {$[2,47]$} \\
\hline Pseudokeronopsis rubra & Qingdao $\left(36^{\circ} 03^{\prime} \mathrm{N} ; 120^{\circ} 20^{\prime} \mathrm{E}\right)$, Shandong & 30 & $\begin{array}{l}\text { MN892435 } \\
-M N 892443\end{array}$ & {$[50]$} \\
\hline Pseudokeronopsis erythrina & $\begin{array}{l}\text { Pearl River Estuary }\left(22^{\circ} 41^{\prime} \mathrm{N} ; 113^{\circ} 38 \mathrm{E}\right) \text {, } \\
\text { Guangdong }\end{array}$ & 15 & $\begin{array}{l}\text { MN892444 } \\
- \text { MN892451 }\end{array}$ & [44] \\
\hline $\begin{array}{l}\text { Pseudoamphisiella } \\
\text { quadrinucleata }\end{array}$ & Clear Water Bay $\left(22^{\circ} 20^{\prime} \mathrm{N}, 114^{\circ} 17^{\prime} \mathrm{E}\right)$, Hong Kong & 33.5 & $\begin{array}{l}\text { MN892452 } \\
\text {-MN892458 }\end{array}$ & [52] \\
\hline Hemigastrostyla enigmatica & Daya Bay $\left(22^{\circ} 43^{\prime} \mathrm{N} ; 114^{\circ} 32^{\prime} \mathrm{E}\right)$, Guangdong & 20 & $\begin{array}{l}\text { MN892459 } \\
- \text { MN892465 }\end{array}$ & [51] \\
\hline Hypotrichidium paraconicum & Maipo Mangrove $\left(22^{\circ} 29^{\prime} \mathrm{N} ; 114^{\circ} 02^{\prime} \mathrm{E}\right)$, Hong Kong & 18 & $\begin{array}{l}\text { MN892466 } \\
- \text { MN892472 }\end{array}$ & [49] \\
\hline Neowallackia sp. & Futian Mangrove $\left(22^{\circ} 31^{\prime} \mathrm{N} ; 114^{\circ} 04^{\prime} \mathrm{E}\right)$, Guangdong & 10 & $\begin{array}{l}\text { MN892473 } \\
- \text { MN892481 }\end{array}$ & [41] \\
\hline
\end{tabular}

kit (TIANGEN, Beijing, China). Subsequently, the purified PCR products were cloned with the pMD18-T Cloning Vector (TaKaRa Biomedicals, Japan) and DH5- $\alpha$ E. coli cells. A total of $2-15$ positive colonies from each population were sequenced in both directions in an ABI Prism 377 Automated DNA Sequencer (Majorbio sequencing facility, Shanghai, China) using primers M13F47 and M13-R48.

Sequence analyses and construction of phylogenetic trees Five datasets were included in the phylogenetic analyses: (1) HSP90-Nuc (98 sequences in total, i.e., Hsp90 nucleotide sequences including 85 that were distinct and newly obtained from the present study together with all 10 ciliate sequences available from the GenBank database); (2) HSP90-Amino (98 sequences in total, i.e., corresponding amino acid sequences of HSP90-Nuc); (3) HSP90-Nuc12 (98 sequences in total, i.e. HSP90-Nuc including only first two codon positions); (4) SSU-rDNA (15 sequences in total, i.e., corresponding SSU rDNA sequences of species in Dataset HSP90-Nuc, expect for three that were absent in GenBank, namely Oxytricha trifallax, Newallackia sp. and Blepharisma intermedium); (5) SSU-HSPNuc12 (15 sequences in total: two-gene combined dataset including SSU-rDNA and HSP90-Nuc including only first two codon positions). In each dataset, three species of Apicomplexa were chosen as the outgroup.
The Hsp90 nucleotide sequences were translated into amino acid sequences by DAMBE 6.3.0.1 software [73]. Intra- and inter-population genetic distances were calculated using MEGA 7.0 [74]. Mean pairwise nucleotide distances were calculated using the Kimura 2-parameter correction model [75]. Mean pairwise amino acid distances were calculated using the Poisson model [76]. Multiple sequence alignments of all nucleotide and amino acid sequences were performed with CLUSTAL W implemented in BioEdit v.7.0.1 [77] and then manually modified in order to trim both ends. Alignments used for subsequent phylogenetic analyses included the following numbers of positions: 1743 (HSP90-Nuc), 386 (HSP90-Amino), 1162 (HSP90-Nuc12), 1806 (SSUrDNA), and 2968 (SSU-HSPNuc12). Models for nucleotide datasets were selected under the Akaike information criterion (AIC) by MrModeltest [78]. GTR + I + G was the best-fitted model for datasets HSP90-Nuc and SSUrDNA. GTR + G was the best-fitted model for datasets HSPNuc12, SSU-HSPNuc12, as well as first and second codon positions of Hsp90 nucleotide sequences. Blosum $62+\mathrm{I}+\mathrm{G}$ was the best-fitted model for the amino acid dataset (HSP90-Amino) selected by AIC as implemented in ProtTest 1.4 [79]. Bayesian inference (BI) analyses were performed with MrBayes 3.1.2 [80]. Markov chain Monte Carlo (MCMC) simulations were run with two sets of four chains for 1,000,000 generations with trees sampled every 100 generations. The first 2500 trees were discarded as burn-in. The remaining trees were 
retained to generate a consensus tree and to calculate the posterior probabilities (PP) of all branches using a majority-rule consensus approach. A maximum likelihood tree (ML) was constructed using online software RAxML-HPC2 on XSEDE (http://www.phylo.org/). The branches of the resulting tree were evaluated by the GTRGAMMA model of nucleotide substitution and the PROTGAMMA model of amino substitution. MEGA7.0 [74] was used to visualize tree topologies. Terminology and systematic classification follow Gao et al., (2016) [1] and Lynn (2008) [43].

Constrained ML trees of Oxytrichinae species and Urosoma species were generated based on HSP90-Nuc, HSP90-Nuc12, HSP90-Amino, SSU-rDNA and SSUHSPNuc12 datasets by RAxML; the remaining taxa were unspecified. Resulting constrained topologies and the unconstrained ML topologies were calculated using

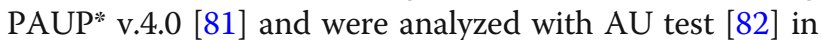
CONSEL v0.1j [83].

\section{Supplementary information}

Supplementary information accompanies this paper at https://doi.org/10. 1186/s12862-020-01653-0.

Additional file 1: Supplementary Table S1. Inter-specific genetic distances of Hsp90 nucleotide and amino acid sequences.

\begin{abstract}
Abbreviations
AIC: Akaike information criterion; BI: Bayesian inference; DNA: Deoxyribonucleic acid; GTR + I + G: General time reversible + invariable sites + gamma model of nucleotide substitution; Hsp/HSP: Heat-shock protein gene; HSP90Amino: Hsp90 amino acid sequences dataset; HSP90-Nuc: Hsp90 nucleotide sequence datasets; HSP90-Nuc12: Hsp90 nucleotide sequences dataset without third codon positions; ITS: Internal transcribed spacer; LSU rDNA: Large subunit rDNA; ML: Maximum likelihood; p1: Population 1; p2: Population 2; PCR: Polymerase chain reaction; sp.: Species; SSU rDNA: Small subunit rDNA; SSU-rDNA: Small subunit rDNA sequence dataset; SSU-HSPNuc12: Two-gene combined dataset including SSU-rDNA and HSP90-Nuc12
\end{abstract}

\section{Acknowledgements}

Many thanks are due to Prof. Weibo Song, Ocean University of China, for his constructive comments to improve the figures. We also thank former and present and members in the Laboratory of Protozoology at both OUC and SCNU, for providing DNA or cells.

\section{Authors' contributions}

ZY did the research design and supervised the phylogenetic analyses. RY carried out the laboratory experiments. QZ and JHX analyzed data and drafted the manuscript. AW revised the manuscript and supervised discussion related to morphological characters. ZS completed the figures and revised the manuscript. All authors have read and approved the manuscript.

\section{Funding}

This work was financially supported by the Marine S\&T Fund of Shandong Province for Pilot National Laboratory for Marine Science and Technology (Qingdao) (2018SDKJ0406-1), the National Natural Science Foundation of China (grant numbers 31772440, 31970486, 31672279), and Guangdong MEPP Fund [NO. GDOE (2019) A23]. The funding bodies had no role in the design or implementation of this study or in preparation of the manuscript.
Availability of data and materials

Sequence data are available in GenBank (Accession Numbers: MN892397MN892481). The datasets used and/or analyses during the current study are available from the corresponding author Zhenzhen Yi on reasonable request.

Ethics approval and consent to participate

Not applicable.

\section{Consent for publication}

Not applicable.

\section{Competing interests}

The authors declare that they have no competing interests.

\section{Author details}

${ }^{1}$ Guangzhou Key Laboratory of Subtropical Biodiversity and Biomonitoring, School of Life Science, South China Normal University, Guangzhou 510631, China. ${ }^{2}$ Pilot National Laboratory for Marine Science and Technology (Qingdao), Qingdao 266237, China. ${ }^{3}$ Department of Life Sciences, Natural History Museum, London SW7 5BD, UK. ${ }^{4}$ Institute of Microbial Ecology and Matter Cycle, School of Marine Sciences, Sun Yat-sen University, Zhuhai 519000, China. ${ }^{5}$ Southern Marine Science and Engineering Guangdong Laboratory (Zhuhai), Zhuhai 519000, China.

Received: 13 March 2020 Accepted: 7 July 2020

Published online: 16 July 2020

\section{References}

1. Gao F, Warren A, Zhang Q, Gong J, Miao M, Sun P, et al. The all-data-based evolutionary hypothesis of ciliated protists with a revised classification of the phylum Ciliophora (Eukaryota, Alveolata). Sci Rep. 2016;6:24874.

2. Hu X, Lin X, Song W. Ciliates atlas: species found in the South China Sea. Beijing: Science Press; 2019

3. Yi Z, Huang L, Yang R, Lin X, Song W. Actin evolution in ciliates (Protist, Alveolata) is characterized by high diversity and three duplication events. Mol Phylogenet Evol. 2016;96:45-54.

4. Zhao Y, Yi Z, Warren A, Song W. Species delimitation for the molecular taxonomy and ecology of the widely distributed microbial eukaryote genus Euplotes (Alveolata, Ciliophora). P Roy Soc B-Biol Sci. 2018;285:20172159.

5. Wang YR, Jiang YH, Liu YQ, Li Y, Katz LA, Gao F, Yan Y. Comparative studies on the polymorphism and copy number variation of mtSSU rDNA in ciliates (Protista, Ciliophora): implications for phylogenetic, environmental, and ecological research. Microorganisms. 2020:8(3):316.

6. Wang $Y R$, Wang $C D$, Jiang $Y H$, Katz LA, Gao F, Yan Y. Further analyses of variation of ribosome DNA copy number and polymorphism in ciliates provide insights relevant to studies of both molecular ecology and phylogeny. Sci China Life Sci. 2019:62:203-14.

7. Lu B, Li L, Hu XZ, Ji D, Al-Rasheid KAS, Song W. Novel contributions to the peritrich family Vaginicolidae (Protista, Ciliophora), with morphological and phylogenetic analyses of three poorly-known species within genera Pyxicola, Cothurnia and Vaginicola. Zool J Linnean Soc. 2019:187:1-30.

8. Shao C, Hu C, Fan Y, Warren A, Lin X. Morphology, morphogenesis and molecular phylogeny of a freshwater ciliate, Monomicrocaryon euglenivorum euglenivorum (Ciliophora, Oxytrichidae). Eur J Protistol. 2019;68:25-36.

9. Budin K, Philippe H. New insights into the phylogeny of eukaryotes based on ciliate Hsp70 sequences. Mol Biol Evol. 1998;15:943-56.

10. Moreira D, Le Guyader H, Philippe $H$. Unusually high evolutionary rate of the elongation factor 1 alpha genes from the Ciliophora and its impact on the phylogeny of eukaryotes. Mol Biol Evol. 1999;16:234-45.

11. Maddison WP. Gene trees in species trees. Syst Biol. 1997:46:523-36.

12. Bernhard D, Schlegel M. Evolution of histone $\mathrm{H} 4$ and $\mathrm{H} 3$ genes in different ciliate lineages. J Mol Evol. 1998:46:344-54.

13. Fernandes NM, Paiva TDS, da Silva-Neto ID, Schlegel M, Schrago CG. Expanded phylogenetic analyses of the class Heterotrichea (Ciliophora, Postciliodesmatophora) using five molecular markers and morphological data. Mol Phylogenet Evol. 2016;95:229-46.

14. Katz LA, Lasek-Nesselquist E, Snoeyenbos-West OL. Structure of the micronuclear a-tubulin gene in the phyllopharyngean ciliate Chilodonella uncinata: implications for the evolution of chromosomal processing. Gene. 2003:315:15-9. 
15. Krenek S, Schlegel M, Berendonk TU. Convergent evolution of heatinducibility during subfunctionalization of the Hsp70 gene family. BMC Evol Biol. 2013;13:49.

16. Rajter L', Vdačný P. Selection and paucity of phylogenetic signal challenge the utility of alpha-tubulin in reconstruction of evolutionary history of freeliving litostomateans (Protista, Ciliophora). Mol Phylogenet Evol. 2018;127: 534-44

17. Yi Z, Katz LA, Song W. Assessing whether alpha-tubulin sequences are suitable for phylogenetic reconstruction of Ciliophora with insights into its evolution in euplotids. PLoS One. 2012;7:e40635.

18. Chen X, Jiang Y, Gao F, Zheng W, Krock TJ, Stover NA, et al. Genome analyses of the new model protist Euplotes vannus focusing on genome rearrangement and resistance to environmental stressors. Mol Ecol Resour. 2019;19:1292-308

19. Feng JM, Jiang CQ, Warren A, Tian M, Cheng J, Liu GL, et al. Phylogenomic analyses reveal subclass Scuticociliatia as the sister group of subclass Hymenostomatia within class Oligohymenophorea. Mol Phylogenet Evol. 2015;90:104-11.

20. Gentekaki E, Kolisko M, Boscaro V. Large-scale phylogenomic analysis reveals the phylogenetic position of the problematic taxon Protocruzia and unravels the deep phylogenetic affinities of the ciliate lineages. Mol Phylogenet Evol. 2014;78:36-42.

21. Gentekaki E, Kolisko M, Gong Y, Lynn D. Phylogenomics solves a longstanding evolutionary puzzle in the ciliate world: the subclass Peritrichia is monophyletic. Mol Phylogenet Evol. 2017;106:1-5.

22. Jiang CQ, Wang GY, Xiong J, Yang WT, Sun ZY, Feng JM, et al. Insights into the origin and evolution of Peritrichia (Oligohymenophorea, Ciliophora) based on analyses of morphology and phylogenomics. Mol Phylogenet Evol. 2019;132:25-35.

23. Strüder-Kypke MC, Lynn DH. Comparative analysis of the mitochondrial cytochrome c oxidase subunit I (COI) gene in ciliates (Alveolata, Ciliophora) and evaluation of its suitability as a biodiversity marker. Syst Biodivers. 2010; 8:131-48.

24. Yi Z, Strüder-Kypke M, Hu X, Lin X, Song W. Sampling strategies for improving tree accuracy and phylogenetic analyses: a case study in ciliate protists, with notes on the genus Paramecium. Mol Phylogenet Evol. 2014;71:142-8.

25. Zhang Q, Simpson A, Song W. Insights into the phylogeny of systematically controversial haptorian ciliates (Ciliophora, Litostomatea) based on multigene analyses. P Roy Soc B-Biol Sci. 2012;279:2625-35.

26. Keeling PJ, Leander BS. Characterisation of a non-canonical genetic code in the oxymonad Streblomastix strix. J Mol Biol. 2003;326:1337-49.

27. Shalchian-Tabrizi K, Minge M, Cavalier-Smith T, Nedreklepp J, Klaveness D, Jakobsen K. Combined heat shock protein 90 and ribosomal RNA sequence phylogeny supports multiple replacements of dinoflagellate plastids. J Eukaryot Microbiol. 2006;53:217-24.

28. Simpson AG, Roger AJ. Protein phylogenies robustly resolve the deep-level relationships within Euglenozoa. Mol Phylogenet Evol. 2004;30:201-12.

29. Stechmann A, Cavalier-Smith T. Phylogenetic analysis of eukaryotes using heat-shock protein Hsp90. J Mol Evol. 2003;57:408-19.

30. Frankel J, Williams NE, Nelsen EM, Keeling PJ. An evaluation of Hsp90 as a mediator of cortical patterning in Tetrahymena. J Eukaryot Microbiol. 2001; 48:147-60.

31. Csermely P, Schnaider T, Soti C, Prohászka Z, Nardai G. The 90-kDa molecular chaperone family: structure, function, and clinical applications. A comprehensive review. Pharmacol Therapeut. 1998;79:129-68.

32. Rutherford SL, Lindquist S. Hsp90 as a capacitor for morphological evolution. Nature. 1998;396:336-42.

33. Lynn DH, Kolisko M. Molecules illuminate morphology: phylogenomics confirms convergent evolution among 'oligotrichous' ciliates. Int J Syst Evol Micr. 2017;67:3676-82

34. Sparvoli D, Richardson E, Osakada H, Haraguchi T, Dacks JB, Turkewitz AP, et al. Remodeling the specificity of an endosomal CORVET tether underlies formation of regulated secretory vesicles in the ciliate Tetrahymena thermophila. Curr Biol. 2018:28:697-710.

35. Cheng T, Wang Y, Huang J, Chen X, Zhao X, Gao S, et al. Our recent progress in epigenetic research using the model ciliate, Tetrahymena thermophila. Mar Life Sci Technol. 2019;1:4-14.

36. Jahn $\mathrm{CL}$, Klobutcher LA. Genome remodeling in ciliated protozoa. Annu Rev Microbiol. 2002:56:489-520.

37. Schmidt SL, Bernhard D, Schlegel M, Fried J. Fluorescence in situ hybridization with specific oligonucleotide rRNA probes distinguishes the sibling species Stylonychia lemnae and Stylonychia mytilus (Ciliophora, Spirotrichea). Protist. 2006;157:21-30.

38. Berger H. Monograph of the Oxytrichidae (Ciliophora, Hypotrichia). Monographiae Biol. 1999;78:1-1080.

39. Berger H. Monograph of the Urostyloidea (Ciliophora, Hypotrichia). Monographiae Biol. 2006:85:1-1304.

40. Berger $\mathrm{H}$. Monograph of the Amphisiellidae and Trachelostylidae (Ciliophora, Hypotrichia). Monographiae Biol. 2008:88:1-737.

41. Berger H. Monograph of the Gonostomatidae and Kahliellidae (Ciliophora, Hypotrichia). Monographiae Biol. 2011;90:1-741.

42. Corliss JO. The ciliated protozoa. Characterization, classification, and guide to the literature, 2nd edn. Oxford: Pergamon Publishers; 1979.

43. Lynn DH. The ciliated protozoa: characterization, classification, and guide to the literature. 3rd ed. Dordrecht: Springer Press; 2008.

44. Chen X, Clamp JC, Song W. Phylogeny and systematic revision of the family Pseudokeronopsidae (Protista, Ciliophora, Hypotricha), with description of a new estuarine species of Pseudokeronopsis. Zool Scr. 2011:40:659-71.

45. Dong J, Li L, Fan X, Ma H, Warren A. Two Urosoma species (Ciliophora, Hypotrichia): a multidisciplinary approach provides new insights into their ultrastructure and systematics. Eur J Protistol. 2020;72:125661.

46. Wang P, Gao F, Huang J, Strüder-Kypke M, Yi Z. A case study to estimate the applicability of secondary structures of SSU-rRNA gene in taxonomy and phylogenetic analyses of ciliates. Zool Scr. 2015:44:574-85.

47. Shao C, Chen L, Pan Y, Warren A, Miao M. Morphology and phylogenetic position of the oxytrichid ciliates, Urosoma salmastra (Dragesco and Dragesco-Kernéis, 1986) Berger, 1999 and U. karinae sinense nov. sspec. (Ciliophora, Hypotrichia). Eur J Protistol. 2014;50:593-605.

48. Xu W, Zhao Y, Pan B, Liu Y, Luo X. Morphology, morphogenesis, and phylogeny of Urosoma caudata (Ehrenberg, 1833) Berger, 1999 (Ciliophora, Hypotrichia) based on a Chinese population. J Eukaryot Microbiol. 2020;67: 76-85.

49. Chen L, Liu W, Liu A, Al-Rasheid KAS, Shao C. Morphology and molecular phylogeny of a new marine hypotrichous ciliate, Hypotrichidium paraconicum n. sp. (Ciliophora, Hypotrichia). J Eukaryot Microbiol. 2013;60: 588-600.

50. Song W, Warren A, Roberts D, Wilbert N, Li L, Sun P, Hu X, Ma H. Comparison and redefinition of four marine, coloured Pseudokeronopsis spp. (Ciliophora: Hypotrichida), with emphasis on their living morphology. Acta Protozool. 2006:45:271-87

51. Shao C, Ding Y, Al-Rasheid KA, Al-Farraj SA, Warren A, Song W. Establishment of a new hypotrichous genus, Heterotachysoma n. gen. and notes on the morphogenesis of Hemigastrostyla enigmatica (Ciliophora, Hypotrichia). Eur J Protistol. 2013;49:93-105.

52. Shen Z, Lin X, Long H, Miao M, Liu H, Al-Rasheid KAS, Song W. Morphology and small subunit rDNA gene sequence of Pseudoamphisiella quadrinucleata n. sp. (Ciliophora, Urostylida) from the South China Sea. J Eukaryot Microbiol. 2008:55:510-4.

53. Song W. Morphology and morphogenesis of the marine ciliate Ponturostyla enigmatica (Dragesco \& Dragesco-Kernéis,1986) Jankowski, 1989 (Ciliophora, Hypotrichida, Oxytrichidae). Eur J Protistol. 2001;37:181-97.

54. Zhang T, Fan X, Gao F, Al-Farraj SA, El-Serehy HA, Song W. Further analyses on the phylogeny of the subclass Scuticociliatia (Protozoa, Ciliophora) based on both nuclear and mitochondrial data. Mol Phylogenet Evol. 2019;139: 106565

55. Zufall RA, Katz LA. Micronuclear and macronuclear forms of $\beta$-tubulin genes in the ciliate Chilodonella uncinata reveal insights into genome processing and protein evolution. J Eukaryot Microbiol. 2007:54:275-82.

56. Bharti D, Kumar S, Terza AL, Chandra K. Morphology and ontogeny of Tetmemena pustulata indica nov. subspec. (Ciliophora, Hypotricha), from the Thane Creek, Mumbai, India. Eur J Protistol. 2019;71:125629.

57. Jiang Y, Zhang T, Vallesi A, Yang X, Gao F. Time-course analysis of nuclear events during conjugation in the marine ciliate Euplotes vannus and comparison with other ciliates (Protozoa, Ciliophora). Cell Cycle. 2019;18: 288-98.

58. Sheng Y, He M, Zhao F, Shao C, Miao M. Phylogenetic relationship analyses of complicated class Spirotrichea based on transcriptomes from three diverse microbial eukaryotes: Uroleptopsis citrina, Euplotes vannus and Protocruzia tuzeti. Mol Phylogenet Evol. 2018:129:338-45.

59. Zhang T, Qi H, Zhang T, Sheng Y, Warren A, Shao C. Morphology, morphogenesis and molecular phylogeny of a new brackish water subspecies, Neourostylopsis flava paraflava nov. subsp. (Ciliophora, 
Hypotrichia, Urostylidae), with redefinition of the genus Neourostylopsis. Eur J Protistol. 2018:66:48-62

60. Israel RL, Pond SLK, Muse SV, Katz LA. Evolution of duplicated alpha-tubulin genes in ciliates. Evolution. 2002:56:1110-22.

61. Shazib SUA, Vdačný P, Slovák M, Gentekaki E, Shin MK. Deciphering phylogenetic relationships and delimiting species boundaries using a Bayesian coalescent approach in protists: a case study of the ciliate genus Spirostomum (Ciliophora, Heterotrichea). Sci Rep. 2019;9:16360.

62. Chen L, Wu W, El-Serehy HA, Hu X, Clamp JC. Morphology, morphogenesis, and phylogeny of an Anteholosticha intermedia (Ciliophora, Urostylida) population from the United States. Eur J Protistol. 2018:65:1-15.

63. Kim KS, Min GS. Morphology and molecular phylogeny of Oxytricha seokmoensis sp. nov. (Hypotrichia: Oxytrichidae), with notes on its morphogenesis. Eur J Protistol. 2019;71:125641.

64. Lian C, Luo X, Warren A, Zhao Y, Jiang J. Morphology and phylogeny of four marine or brackish water spirotrich ciliates from China, with descriptions of two new species. Eur J Protistol. 2020;72:125663.

65. Lu X, Huang J, Shao C, Berger H. Morphology, cell-division, and phylogeny of Schmidingerothrix elongata spec. nov. (Ciliophora, Hypotricha), and brief guide to hypotrichs with Gonostomum-like oral apparatus. Eur J Protistol. 2018;62:24-42.

66. Park KM, Jung JH, Jeong HK, Min GS, Kim S. Morphology, morphogenesis, and molecular phylogeny of a new freshwater ciliate, Gonostomum jangbogoensis n. sp. (Ciliophora, Hypotricha), from Victoria Land, Antarctica. Eur J Protistol. 2020;73:125669.

67. Wang J, Li J, Shao C. Morphology, morphogenesis, and molecular phylogeny of a novel saline soil ciliate, Heterourosomoida sinica $\mathrm{n}$. sp. (Ciliophora, Hypotrichia). Eur J Protistol. 2020;73:125666.

68. Jung JH, Cho J, Jang YH, Gil DY. Morphology and molecular phylogeny of Holostichides terrae nov. spec. (Ciliophora: Spirotrichea) with discussion on the possible non-monophyly of Holostichides. Eur J Protistol. 2018;62:69-78.

69. Shao C, Lyv Z, Pan Y, Al-Rasheid KA, Yi Z. Morphology and phylogenetic analysis of two oxytrichid soil ciliates from China, Oxytricha paragranulifera n. sp. and Oxytricha granulifera Foissner and Adam, 1983 (Protista, Ciliophora, Hypotrichia). Int J Syst Evol Micr. 2014;64:3016-27.

70. Gao F, Huang J, Zhao Y, Li L, Liu W, Miao M, et al. Systematic studies on ciliates (Alveolata, Ciliophora) in China: Progress and achievements based on molecular information. Eur J Protistol. 2017;28:2062-73.

71. Lyu Z, Li J, Qi S, Yu Y, Shao C. Morphology and morphogenesis of a new soil urostylid ciliate, Australothrix xianiensis nov. spec. (Ciliophora, Hypotrichia). Eur J Protistol. 2018;64:72-81.

72. Chen T, Yi Z, Huang J, Lin X. Evolution of the germline actin gene in hypotrichous ciliates: multiple nonscrambled IESs at extremely conserved locations in two urostylids. J Eukaryot Microbiol. 2015;62:188-95.

73. Xia X. DAMBE6: new tools for microbial genomics, phylogenetics, and molecular evolution. J Hered. 2017;108:431-7.

74. Kumar S, Stecher G, Tamura K. MEGA7: molecular evolutionary genetics analysis version 7.0 for bigger datasets. Mol Biol Evol. 2016;33:1870-4.

75. Kimura M. A simple method for estimating evolutionary rate of base substitutions through comparative studies of nucleotide sequences. J Mol Evol. 1980;16:111-20

76. Nei M, Kumar S. Molecular evolution and phylogenetics. New York: Oxford University Press; 2000.

77. Hall TA. BioEdit: a user-friendly biological sequence alignment program for windows 95/98/NT. Nuclc Acids Symposium Series. 1999;41(41):95-8.

78. Nylander JAA. MrModeltest V2. Program distributed by the author. Uppsala: Evolutionary Biology Centre, Uppsala University; 2004.

79. Abascal F, Zardoya R, Posada D. ProtTest: selection of best-fit models of protein evolution. Bioinformatics. 2005;21:2104-5.

80. Ronquist F, Huelsenbeck JP. MrBayes 3: Bayesian phylogenetic inference under mixed models. Bioinformatics. 2003;19:1572-4.

81. Swofford DL. PAUP*. Phylogenetic analysis using parsimony (*and other methods). Version 4. Sunderland: Sinauer Associates; 2002.

82. Shimodaira $\mathrm{H}$. An approximately unbiased test of phylogenetic tree selection. Syst Biol. 2002;51:492-508.

83. Shimodaira H, Hasegawa M. Consel: for assessing the confidence of phylogenetic tree selection. Bioinformatics. 2001;17:1246-7.

\section{Publisher's Note}

Springer Nature remains neutral with regard to jurisdictional claims in published maps and institutional affiliations.

\section{Ready to submit your research? Choose BMC and benefit from}

- fast, convenient online submission

- thorough peer review by experienced researchers in your field

- rapid publication on acceptance

- support for research data, including large and complex data types

- gold Open Access which fosters wider collaboration and increased citations

- maximum visibility for your research: over $100 \mathrm{M}$ website views per year

At BMC, research is always in progress.

Learn more biomedcentral.com/submissions 